\title{
ERRATUM
}

\section{Interactive and individual effects of dietary non-digestible carbohydrates and oils on DNA damage, SCFA and bacteria in the large bowel of rats - ERRATUM}

Michael A. Conlon and Anthony R. Bird

doi:10.1017/S0007114508056031, Published by Cambridge University Press.

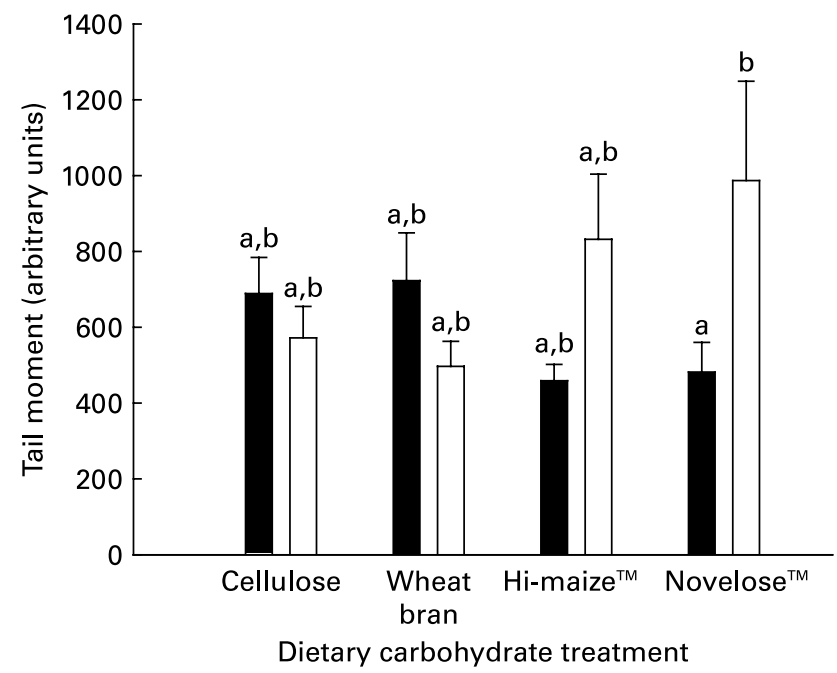

Fig. 1. Effects of diets varying in the sources of non-digestible carbohydrates and oils $\left(\boldsymbol{}\right.$, , Sunola ${ }^{\mathrm{TM}}$ oil; $\square$, fish oil) on colonic DNA damage in rats. The comet assay was used to determine the number of single-strand DNA breaks in the colonocytes extracted from the colon and the resulting comet tail moments (comet tail length $\times$ per cent DNA in the tail) are presented. Values are presented as the mean with its standard error $(n 8)$. ${ }^{\text {,b }}$ Mean values with unlike superscript letters were significantly different $(P<0.05)$.

In error, the key to Fig. 1 was printed incorrectly. The corrected figure is reprinted here ${ }^{(1)}$.

\section{Reference}

1. Conlon MA \& Bird AR (2009) Interactive and individual effects of dietary non-digestible carbohydrates and oils on DNA damage, SCFA and bacteria in the large bowel of rats. Br J Nutr 101, 1171-1177, published by Cambridge University Press, doi:10.1017/S0007114508056031. 